\title{
Nuclear DNA content in the genera Zea and Sorghum. Intergeneric, interspecific and intraspecific variation
}

\author{
D. A. Laurie and \\ M. D. Bennett
}

Plant Breeding Institute, Maris Lane, Trumpington, Cambridge CB2 2LQ, England

Microdensitometry measurements showed that $4 C$ DNA content varied significantly both within the genus $Z e a$ as a whole and within maize (Zea mays ssp. mays) itself. The DNA contents of diploid teosintes from Mexico and northern Guatemala (Zea mays ssp. mexicana, Zea mays ssp. parviglumis and Zea diploperennis) were within the range recorded for maize $(9.84$ to $13.49 \mathrm{pg}$ ), but the DNA content of a diploid teosinte from southern Guatemala (Zea luxurians) was about 50 per cent higher (18.29 to $18.47 \mathrm{pg})$. The DNA content of maize was three to four times greater than that of diploid Sorghum bicolor $(3 \cdot 12$ to $3.47 \mathrm{pg})$. In contrast to the situation in maize no significant differences in DNA content were found between accessions of diploid Sorghum bicolor.

\section{INTRODUCTION}

As part of a cooperative project with CIMMYT* to investigate the feasibility of obtaining hybrids between maize (Zea mays (L.) ssp. mays) and grain sorghum (Sorghum bicolor (L.) Moench), the range of $4 C$ DNA contents within the genera $Z e a$ and Sorghum was investigated. The rationale for these experiments was first, that the likelihood of producing karyotypically stable hybrids may be influenced by nucleotypic factors such as the relative sizes of the parental genome, and second, that a knowledge of parental genomes sizes would facilitate the unambiguous identification of genomes or individual chromosomes in any putative intergeneric hybrid.

Previously published estimates of the $4 C$ DNA content for maize range from $9 \cdot 4$ to $25 \cdot 2$ pg (Bennett and Smith, 1976; Hake and Walbot, 1980; Bennett et al., 1983; Barlow and Rathfelder, 1984). It is questionable whether differences of this magnitude are real, but some variation in DNA content might be expected since maize races frequently differ in the number of heterochromatic knobs (Kato, 1976; McClintock et al., 1981). Unfortunately some of the previous studies did not state which maize genotype was used.

\footnotetext{
* Centro Internacional de Mejoramiento de Maiz y Trigo,
} Mexico.
Apart from Barlow and Rathfelder's (1984) estimate of $7 \cdot 1 \mathrm{pg}$ for the $2 C$ DNA content of an unspecified accession of Euchlaena mexicana (annual teosinte), no published data are available on the DNA content of other Zea species or subspecies. It is therefore of interest to determine the extent of variation within and between these taxa.

The $4 C$ DNA contents of several members of what is now classified as the Sorghum bicolor complex (De Wet, 1978), which like maize have diploid chromosome numbers of $2 n=20$, were reported to range from 11.7 to $22.8 \mathrm{pg}$ (Paroda and Rees, 1971). However root-tip squash preparations show that the chromosomes of $S$. bicolor are small compared to those of maize (fig. 1) suggesting that the previously published values may have been overestimated. Several Sorghum taxa were examined in order to resolve this question.

\section{MATERIALS AND METHODS}

\section{(a) Materials}

Measurements of $4 C$ nuclear DNA content were made on a representative collection of wild members of the genus Zea and on 11 stocks of maize from the United States and Mexico (table 1). Measurements were also made of eight accessions of $2 n=20$ grain sorghum ( $S$. bicolor ssp. bicolor), 2 accessions of $2 n=40$ Sorghum and 1 accession of the $2 n=10$ Parasorghum $S$. versicolor (table 2). 


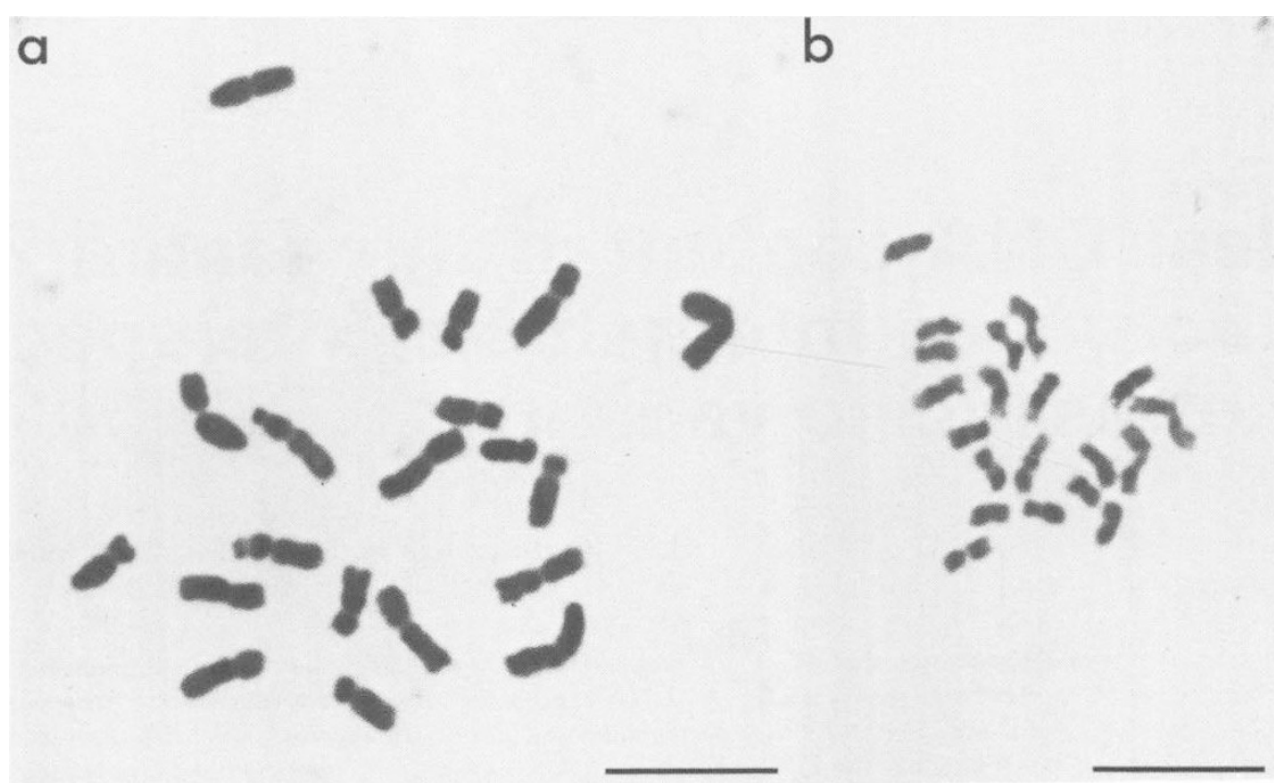

Figure 1 Root-tip metaphase chromosomes stained with Feulgen and propionic orcein. (a) Zea mays ssp. mays Seneca 60. (b) Sorghum bicolor ssp. bicolor CMS G3E A line 41-42 PR.84A. Bar represents $10 \mu \mathrm{m}$.

\section{(b) Microdensitometry}

Seeds were germinated on moist Whatman No. 1 filter paper in an incubator at $25^{\circ} \mathrm{C}$ and 3 to 4 day old root-tips were fixed for at least 24 hours in $3: 1$ ethanol/acetic acid. Fixed root-tips were rinsed in distilled water for $1 \mathrm{~min}$, hydrolysed in $1 \mathrm{~N} \mathrm{HCl}$ for $12 \mathrm{~min}$ and Feulgen stained for 2 hours at room temperature. They were then given three $10 \mathrm{~min}$ washes in sulphur dioxide water and squashed in 45 per cent acetic acid. Three measurements of each of 10 late prophase or metaphase cells from each of three replicate slides were made on the same day using a Vickers M86 scanning microdensitometer. If less than 10 cells were found on a slide, extra slides were measured. In addition an extra slide was measured wherever possible for wild accessions in an effort to reduce possible errors arising from variation in DNA content due to polymorphism for heterochromatic segments.

Hordeum vulgare (L.) cv. Sultan (4C DNA content $=22 \cdot 2 \mathrm{pg}$ ) was used as a standard for calibrating the DNA content of the Zea taxa and Vigna radiata (L.) Wilczek cv. Berken (4C DNA content $=2 \cdot 1 \mathrm{pg}$ ) as a standard for calibrating the Sorghum taxa. The DNA content of $V$. radiata was checked against that of $H$. vulgare cv. Sultan and the value obtained $(4 C=1.99 \mathrm{pg})$ was close to that of previous microdensitometry and reassociation kinetics experiments (Bennett et al., 1982). The standard value of $2 \cdot 1 \mathrm{pg}$ was therefore used to calibrate all Sorghum taxa.
In order to ensure greater accuracy in the DNA measurements, hydrolysis curves were determined for the two standards and for Z. mays ssp. mays Seneca 60 and $S$. bicolor ssp. bicolor S275. In all four cases the maximum absorbance at $558 \mathrm{~nm}$ occurred after $12 \mathrm{~min}$ hydrolysis in $1 \mathrm{~N} \mathrm{HCl}$ at $60^{\circ} \mathrm{C}$.

\section{(c) Taxonomy}

The classification of the genus Zea used in this paper is that given in Doebley and Iltis (1980) and Iltis and Doebley (1980), while the classification of the genus Sorghum is that given in De Wet (1978).

\section{(d) Statistical analysis}

Comparisons of DNA content between taxa were made using analyses of variance. In tables 1 and 5 the standard errors were calculated from the between replicate mean squares of tables 2 and 6 respectively as $\sqrt{m s / n}$ where $n$ was the number of cells measured per accession.

\section{RESULTS}

The genus Zea

Table 1 gives the $4 \mathrm{C}$ DNA contents of $28 \mathrm{Zea}$ accessions. An analysis of variance of the overall 
Table 1 DNA content of $4 C$ mitotic nuclei in the genus $\mathrm{Zea}$

\begin{tabular}{|c|c|c|c|c|c|}
\hline & Source & $2 n$ & $\begin{array}{l}\text { Number of } \\
\text { replicate } \\
\text { experiments }\end{array}$ & $\begin{array}{l}4 C \text { DNA } \\
(\mathrm{pg})\end{array}$ & SE \\
\hline \multicolumn{6}{|l|}{ Section Zea } \\
\hline \multicolumn{6}{|l|}{ Zea mays ssp. mays } \\
\hline \multicolumn{6}{|l|}{ Commercial hybrid } \\
\hline Seneca 60 & 1 & 20 & 4 & $9 \cdot 84$ & $0 \cdot 202$ \\
\hline \multicolumn{6}{|l|}{ Open pollinated variety } \\
\hline Knobless Tama Flint Ac603B & 1 & 20 & 1 & $10 \cdot 28$ & $0 \cdot 367$ \\
\hline \multicolumn{6}{|l|}{ Inbred lines } \\
\hline Va35 & 2 & 20 & 3 & $10 \cdot 31$ & $0 \cdot 226$ \\
\hline Oh43 & 1 & 20 & 1 & $10 \cdot 58$ & 0.329 \\
\hline W64A & 3 & 20 & 2 & $10 \cdot 93$ & $0 \cdot 300$ \\
\hline KYS & 1 & 20 & 1 & $11 \cdot 04$ & 0.367 \\
\hline \multicolumn{6}{|l|}{ Races } \\
\hline Palomero Toluqueño Mexico 5 BA.70 539-546 & 4 & 20 & 1 & $11 \cdot 26$ & 0.367 \\
\hline Sinaloa 2 TL.72B 5-8 & 4 & 20 & 1 & $11 \cdot 65$ & 0.424 \\
\hline Yucatan 7 TL.72B 1-4 & 4 & 20 & 1 & $11 \cdot 92$ & 0.278 \\
\hline Zapalote Chico & 1 & 20 & 1 & $13 \cdot 19$ & 0.424 \\
\hline Oaxaca 50 Tep.60A 5269 & 4 & 20 & 3 & $13 \cdot 49$ & $0 \cdot 244$ \\
\hline \multicolumn{6}{|l|}{ Zea mays ssp. mexicana (Nobogame teosinte) } \\
\hline \multicolumn{5}{|l|}{ ssp. mexicana (Central Plateau teosinte) } & $0 \cdot 382$ \\
\hline Puga 11066 & 5 & 20 & 2 & $10 \cdot 53$ & $0 \cdot 277$ \\
\hline Doebley 625 & 5 & 20 & 3 & $11 \cdot 23$ & $0 \cdot 240$ \\
\hline \multicolumn{6}{|l|}{ ssp. mexicana (Chalco teosinte) } \\
\hline Doebley 642 & 5 & 20 & 1 & $11 \cdot 85$ & 0.377 \\
\hline K68-6 & 4 & 20 & 1 & $12 \cdot 21$ & 0.465 \\
\hline K68-1 & 4 & 20 & 1 & $12 \cdot 51$ & 0.424 \\
\hline K65-1 & 4 & 20 & 3 & $12 \cdot 88$ & 0.257 \\
\hline \multicolumn{6}{|l|}{ Zea mays ssp. parviglumis var. parviglumis (Balsas teosinte) } \\
\hline Beadle and Kato Site 6 & 5 & 20 & 1 & $11 \cdot 19$ & $0 \cdot 367$ \\
\hline Puga 11065 & 5 & 20 & 1 & $11 \cdot 60$ & 0.424 \\
\hline Beadle's El Salado & 5 & 20 & 1 & $11 \cdot 74$ & $0 \cdot 346$ \\
\hline K67-17 & 4 & 20 & 1 & $11 \cdot 88$ & 0.424 \\
\hline K67-7 & 4 & 20 & 1 & $12 \cdot 39$ & 0.439 \\
\hline \multicolumn{6}{|c|}{ Zea mays ssp. parviglumis var. huehuetanangensis (Huehuetenango teosinte) } \\
\hline Iltis and Lind G-120 & 5 & 20 & 1 & $12 \cdot 18$ & $0 \cdot 367$ \\
\hline \multicolumn{6}{|l|}{ Section Luxuriantes } \\
\hline \multicolumn{6}{|l|}{ Zea luxurians (Guatemala teosinte) } \\
\hline Iltis G-5 & 5 & 20 & 1 & $18 \cdot 29$ & 0.424 \\
\hline Iltis $\mathrm{G}-42$ & 5 & 20 & 2 & $18 \cdot 47$ & $0 \cdot 278$ \\
\hline \multicolumn{6}{|l|}{ Zea diploperennis (Diploid perennial teosinte) } \\
\hline Iltis 1190 & 5 & 20 & 1 & $10 \cdot 57$ & $0 \cdot 367$ \\
\hline \multicolumn{6}{|l|}{ Zea perennis (Tetraploid perennial teosinte) } \\
\hline Collins collection (Beadle) & 5 & 40 & 1 & $21 \cdot 13$ & 0.367 \\
\hline
\end{tabular}

Seed sources: (1) Professor D. B. Walden, Department of Botany, Western Ontario University, Ontario, Canada; (2) Dr J. D. Smith, Department of Soil and Crop Science, Texas A \& M University, College Station, TX 77843, USA; (3) Professor J. G. Scandalios, Department of Genetics, North Carolina State University, Raleigh, NC 27695-7614, USA; (4) Centro Internacional de Mejoramiento de Maiz y Trigo (CIMMYT), Mexico. Collection sites for the teosinte accessions are given in Kato Y (1976) and McClintock et al. (1981); (5) Professor J. F. Doebley, Department of Biology, Texas A \& M University, College Station, TX 77843, U.S.A. Collection sites are given in Doebley (1983) and Doebley et al. (1984) except for: (a) Z. mays ssp. mexicana "Doebley 642", 7.5 km SE of Chalco city limits at $\mathrm{km} 17.5$ on road to Tlalmanalco $19^{\circ} 13^{\prime} \mathrm{N}, 98^{\circ} 49^{\prime} \mathrm{W}$, altitude $2400 \mathrm{~m}$; (b) Z. mays ssp. parviglumis var. parviglumis "Beadle and Kato Site 6", $79 \mathrm{~km}$ S of Valle Bravo, estimated to be $18^{\circ} 35^{\prime} \mathrm{N}, 99^{\circ} 57^{\prime} \mathrm{W}$, altitude $900 \mathrm{~m}$ (Doebley pers. comm).

data revealed significant differences between species and between accessions within species despite significant variation between replicate experiments (table 2).

Variation between species was accounted for by the values for the tetraploid $Z$. perennis
$(21 \cdot 13 \mathrm{pg})$ and the diploid southern Guatemala teosinte $Z$. luxurians ( 18.29 to $18.47 \mathrm{pg}$ ) which had 36 to 88 per cent more DNA than other diploid taxa $(9.84$ to $13.49 \mathrm{pg})$.

Table 1 also indicates two further levels of variation. Firstly, there was remarkable variation 
Table 2 Analysis of variance of $4 C$ DNA content in the genus Zea

\begin{tabular}{lrrr}
\hline & $d f$ & \multicolumn{1}{c}{$m s$} & $p$ \\
\hline $\begin{array}{l}\text { Between species } \\
\text { Between subspecies } \\
\quad \text { within species }\end{array}$ & 3 & 2637.788 & $<0.025$ \\
$\begin{array}{l}\text { Between races } \\
\quad \text { within subspecies }\end{array}$ & 3 & 51.599 & ns \\
$\begin{array}{l}\text { Between accessions } \\
\text { within species/ } \\
\text { subspecies/races }\end{array}$ & 19 & 71.336 & ns \\
$\begin{array}{l}\text { Between replicates } \\
\quad \text { within accessions }\end{array}$ & 14 & 5.400 & $<0.001$ \\
$\begin{array}{l}\text { Between slides } \\
\quad \text { within replicates }\end{array}$ & 49 & 0.841 & $<0.001$ \\
$\begin{array}{l}\text { Error } \\
\text { Total }\end{array}$ & 1368 & 0.344 & \\
\hline
\end{tabular}

The between races item compares the Nobogame, Central Plateau, Chalco, Balsas and Huehuetenango teosintes after subtracting the between subspecies variation. "Races" of maize are more properly regarded as separate accessions and all maize stocks have therefore been included in the between accessions comparison.

in maize itself which was significant despite significant differences between replicate experiments (table 3). The commercial hybrid sweetcorn "Seneca 60" had the lowest DNA content $(9 \cdot 84 \mathrm{pg})$ while the Mexican race Zapalote Chico (accession Oaxaca 50) had the highest (13.49), a difference of 37 per cent. Three races of Mexican maize regarded as "primitive" by taxonomists (Doebley, 1983), namely Palomero Toluqueño $11 \cdot 26 \mathrm{pg}$, Chapalote $11.65 \mathrm{pg}$ and Nal-Tel $11.92 \mathrm{pg}$, had DNA contents which were similar to those of teosintes from Mexico and northern Guatemala (Z. mays ssps. mexicana and parviglumis).

Secondly, table 1 also indicates that there may be differences in DNA content between the five "races" of teosinte classed in $Z$. mays (the Nobogame, Central Plateau and Chalco teosintes of ssp. mexicana and the Balsas and Huehuetenango teosintes of ssp. parviglumis). In particular the Chalco teosintes of ssp. mexicana

Table 3 Analysis of variance of $4 C$ DNA content in maize

\begin{tabular}{lccc}
\hline & $d f$ & $m s$ & $p$ \\
\hline $\begin{array}{l}\text { Between accessions } \\
\begin{array}{l}\text { Between replicates } \\
\text { within accessions }\end{array}\end{array}$ & 10 & 102.980 & $<0.001$ \\
$\begin{array}{l}\text { Between slides } \\
\text { within replicates }\end{array}$ & 27 & 3.492 & $<0.001$ \\
$\begin{array}{l}\text { Error } \\
\text { Total }\end{array}$ & $\frac{643}{688}$ & 0.619 & $<0.001$ \\
\hline
\end{tabular}

had higher DNA contents than the Nobogame and Central Plateau teosintes of ssp. mexicana. The analysis in table 2 did not give a significant result for the between races comparison but this may have been because this item was tested against a between accessions item which contained all the maize stocks. Since maize itself was shown to be highly variable (see above) it may be more informative to consider these five teosintes separately. When this was done there were significant differences between races (table 4).

\section{The genus Sorghum}

Table 5 gives the $4 C$ DNA contents of 11 Sorghum accessions. An analysis of variance of the overall data showed significant differences between species but no significant differences within species other than that due to differences in ploidy level (table 6). The difference between species was due to the value for the tetraploid $S$. halepense $(6.61 \mathrm{pg})$ and to that of the $2 n=10$ Parasorghum $S$. versicolor $(8.49 \mathrm{pg})$. The latter is known to have large chromosomes in comparison to those of $S$. bicolor ( $\mathrm{Gu}$ et al., 1984). The DNA contents of the diploid $2 n=20$ accessions of $S$. bicolor, the species in which all cultivated grain sorghums are classified, ranged from $3 \cdot 12$ to 3.47 pg but in contrast to the situation in maize this variation was not significant.

The Sorghum taxa examined all had lower DNA contents that those found in Zea (Table 1) and, not surprisingly, a between genera comparison was highly significant $(p<0 \cdot 001)$.

Table 4 Analysis of variance of $4 C$ DNA content in wild members of $Z$. mays (the Nobogame, Central Plateau and Chalco teosintes of ssp. mexicana and the Balsas and Huehuetenango teosintes of ssp. parviglumis)

\begin{tabular}{lccc}
\hline & $d f$ & $m s$ & $p$ \\
\hline $\begin{array}{l}\text { Between subspecies } \\
\text { within Z. mays }\end{array}$ & 1 & 0.544 & $\mathrm{~ns}$ \\
$\begin{array}{l}\text { Between "races" } \\
\text { within subspecies }\end{array}$ & 3 & 71.335 & $<0.025$ \\
$\begin{array}{l}\text { Between accessions } \\
\quad \text { within taxa }\end{array}$ & 8 & 10.257 & $\mathrm{~ns}$ \\
$\begin{array}{l}\text { Between replicates } \\
\quad \text { within accessions }\end{array}$ & 5 & 9.452 & $\mathrm{~ns}$ \\
$\begin{array}{l}\text { Between slides } \\
\quad \text { within replicates }\end{array}$ & 17 & 3.949 & $<0.001$ \\
$\begin{array}{l}\text { Error } \\
\text { Total }\end{array}$ & $\frac{555}{589}$ & 0.274 & \\
\hline
\end{tabular}

As in table 2 the between races item compares the Nobogame, Central Plateau, Chalco, Balsas and Huehuetenango teosintes after subtracting the between subspecies variation. 
Table 5 DNA content of $4 C$ mitotic nuclei in the genus Sorghum

\begin{tabular}{|c|c|c|c|c|c|}
\hline & Source & $2 n$ & $\begin{array}{l}\text { Number of } \\
\text { replicate } \\
\text { experiments }\end{array}$ & $\begin{array}{l}4 C \text { DNA } \\
(\mathrm{pg})\end{array}$ & SE \\
\hline \multicolumn{6}{|l|}{ Section Sorghum } \\
\hline SII TL80B & 1 & 20 & 1 & $3 \cdot 12$ & $0 \cdot 122$ \\
\hline S275 TL80B & 1 & 20 & 1 & $3 \cdot 20$ & $0 \cdot 122$ \\
\hline S9B BA81 & 1 & 20 & 1 & $3 \cdot 23$ & 0.125 \\
\hline CMS cv. G3E A line 41.42 PR.84A & 1 & 20 & 3 & $3 \cdot 47$ & 0.080 \\
\hline race caffrorum & 2 & 20 & 1 & $3 \cdot 24$ & $0 \cdot 165$ \\
\hline race caffrorum & 3 & 20 & 1 & $3 \cdot 31$ & $0 \cdot 124$ \\
\hline race durra & 2 & 20 & 3 & $3 \cdot 26$ & 0.098 \\
\hline race nervosum & 2 & 20 & 1 & $3 \cdot 27$ & $0 \cdot 154$ \\
\hline \multicolumn{6}{|l|}{ Sorghum bicolor ssp. arundinaceum } \\
\hline race verticilliflorum & 3 & 40 & 1 & $6 \cdot 70$ & $0 \cdot 149$ \\
\hline \multicolumn{6}{|l|}{ Sorghum halepense } \\
\hline race almum & 3 & 40 & 2 & $6 \cdot 61$ & 0.090 \\
\hline \multicolumn{6}{|l|}{ Section Parasorghum } \\
\hline Sorghum versicolor & 3 & 10 & 1 & $8 \cdot 49$ & 0.141 \\
\hline
\end{tabular}

Seed sources: (1) Centro Internacional de Mejoramiento de Maiz y Trigo (CIMMYT), Mexico. CMS is a cytoplasmic male sterile line. (2) Zentralinstitut fur Genetik und Kulturpflanzenforschung, 4325 Gatersleben, DDR. (3) Plant Introduction Officer, Division of Plant and Seed Control, Pretoria, South Africa.

\section{DISCUSSION}

The present results reveal significant differences in $4 C$ DNA content between and within taxa in the genus Zea. Of particular interest is the observation that maize itself shows considerable variation for this character, with the highest DNA content (13.49 pg in Zapalote Chico Oaxaca 50) being 37 per cent higher than the lowest $(9 \cdot 84 \mathrm{pg}$ in Seneca 60 ). As only a limited number of accessions were studied in the present work the full range of DNA content in maize may be even greater.

Table 6 Analysis of variance of $4 C$ DNA content in the genus Sorghum

\begin{tabular}{lccc}
\hline & $d f$ & $m s$ & $p$ \\
\hline $\begin{array}{l}\text { Between species } \\
\begin{array}{l}\text { Between accessions } \\
\text { within ploidy levels }\end{array}\end{array}$ & 2 & 571.855 & $<0.001$ \\
$\begin{array}{l}\text { Between replicates } \\
\text { within accessions }\end{array}$ & 5 & 0.568 & ns \\
$\begin{array}{l}\text { Between slides } \\
\text { within replicates }\end{array}$ & 19 & 0.596 & $<0.025$ \\
$\begin{array}{l}\text { Error } \\
\text { Total }\end{array}$ & $\frac{454}{488}$ & 0.727 & ns \\
\hline
\end{tabular}

The between species item was not tested against a between subspecies item since the latter would contain both diploid and tetraploid accessions. Instead the between species item was compared to a between accessions within ploidy levels item.
Significant variation between maize cultivars has also been found in an independent study (Rayburn et al., 1985). The values obtained for the three accessions included in both investigations were in good agreement $(10 \cdot 28$ vs. $10 \cdot 19 \mathrm{pg}$ for the Knobless Tama Flint, $11.04 \mathrm{vs.} 11 \cdot 20 \mathrm{pg}$ for KYS and 11.92 vs. $11 \cdot 22 \mathrm{pg}$ for Nal-Tel).

It is of interest to consider the variation in maize DNA content in more detail. Previous workers have noted that knob number decreases with increasing latitude of cultivation for maize races grown in the U.S.A. (Anderson and Brown, 1952) and decreases with increasing altitude for maize races grown in Mexico (Bennett, 1976). Rayburn et al. (1985) have now shown significant positive correlations between $\mathrm{C}$-band number (i.e., knob number), per cent $\mathrm{C}$-band heterochromatin and DNA content and have also shown that DNA content decreases significantly with increasing latitude. This provides convincing evidence that variation in DNA content in maize is largely caused by differences in the amount of heterochromatin and that previously reported correlations between geographical location and knob number involve differences in nuclear DNA content. The fact that such correlations exist suggests that these characters have adaptive significance in Zea and are, therefore, of potential agricultural interest.

Observations in the present study were compatible with the results cited above. For example, 
Seneca 60, which had the lowest DNA content, and which was from New York State in the USA had only six blocks of heterochromatin on $C$. banded root-tip chromosomes. The Mexican race Zapalote Chico from southern Oaxaca (Oaxaca 50), which had the highest DNA content, had up to $24 \mathrm{C}$-bands including that of the K10 chromosome (fig. 2).

It seems reasonable to postulate that variation in heterochromatin also contributes to the differences in DNA content found between annual teosintes from Mexico. The present data on DNA content are consistent with data summarised in McClintock et al. (1981) which show that the northern races Nobogame and Central Plateau have on average fewer or smaller heterochromatic knobs than Chalco and, to a lesser extent, Balsas teosintes. However, this picture is complicated by the fact that the Balsas teosintes themselves appear to be heterogeneous (Smith et al., 1982). It should be noted, however, that the teosintes appear to differ from maize in the relationship between DNA content and altitude. In contrast to the situation in maize it is the annual teosinte from the highest altitude (race Chalco) which has the highest DNA contents.

$Z$. luxurians (Guatemala teosinte) is conspicuously different from other $2 n=20$ members of the genus in having considerably more DNA.
This provides further evidence of a clear separation of $Z$. luxurians from both maize and the remaining teosintes (cf. Timothy et al., 1979; Mastenbroek et al., 1981; Smith et al., 1981; 1982; 1984; Doebley et al., 1984).

Variation in the amount of heterochromatin would appear to be an important cause of differences in DNA content between Zea taxa but there are two pieces of evidence which suggest that it is not the only source of such variation. First, the Knobless Tama Flint (KTF), which is devoid of detectable C-band positive material (Mastenbroek and de Wet, 1983; Rayburn et al., 1985), was found to have a significantly higher DNA content than Gaspé Flint, which has 4 C-bands (Rayburn et al., 1985). Results from the present study suggest that KFT also has a higher DNA content than Seneca 60 , although the KTF measurements were unreplicated. Second, $Z$. luxurians has by far the highest DNA content of the diploid Zeas but does not appear to have sufficient heterochromatin to account for this difference (Mastenbroek and de Wet, 1983).

The present results also show that the DNA content of Sorghum is much lower than previously reported and that there is no significant variation in DNA content between the $2 n=20$ Sorghum accessions studied. The $4 C$ DNA contents of a number of $2 n=20$ Sorghum taxa, including three

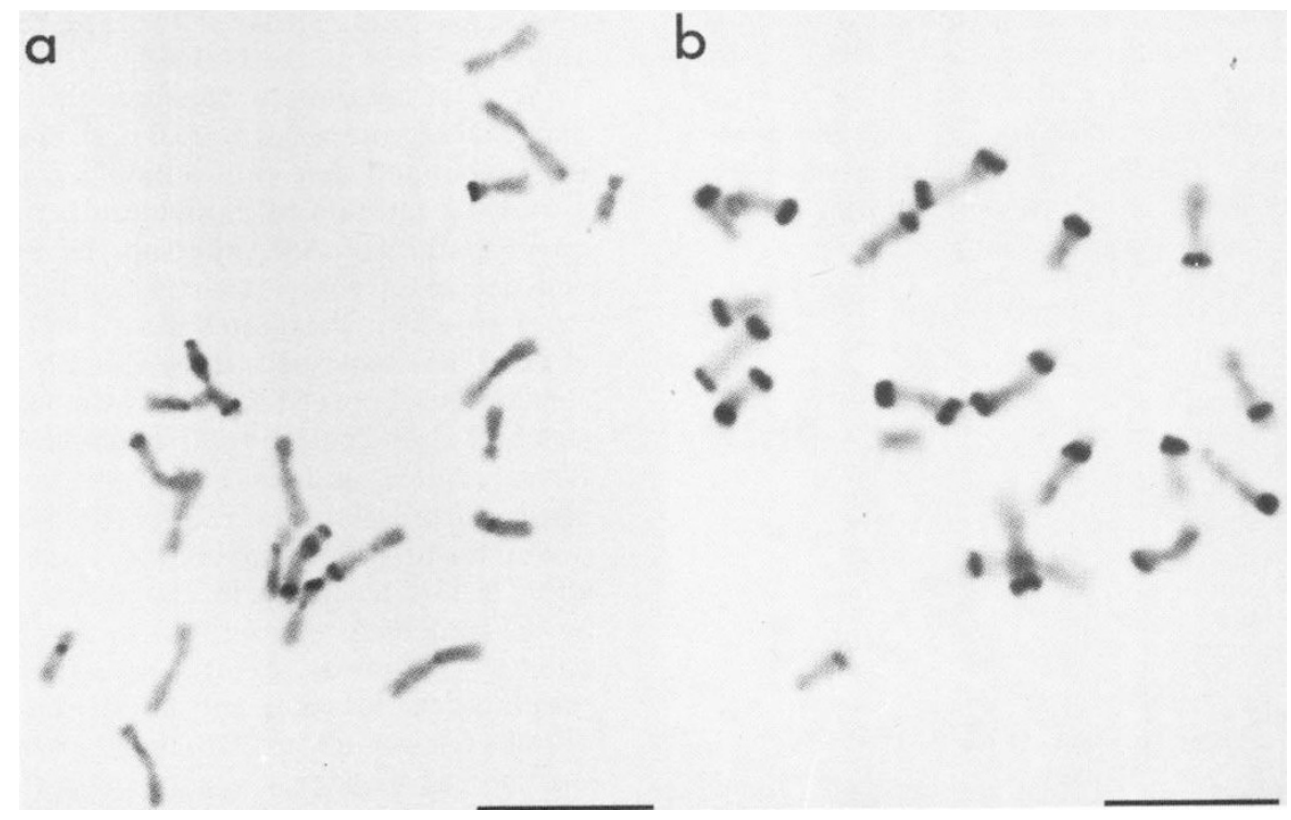

Figure 2 C-banded root-tip metaphase chromosomes. (a) Zea mays ssp. mays Seneca 60. (b) Zea mays ssp. mays Zapalote Chico Oaxaca 50. Bar represents $10 \mu \mathrm{m}$. 
in the present study (races durra, caffrorum and nervosum), were reported to range from 11.7 to $22 \cdot 8$ pg (Paroda and Rees, 1971). These values are comparable to those for maize and barley $(H$. vulgare) respectively (Bennett and Smith, 1976; Bennett et al., 1983; this paper), but measurements made in this laboratory estimate the $4 C$ DNA content to be in the range $3 \cdot 0$ to $3 \cdot 47 \mathrm{pg}$ for $2 n=20$ accessions (Bennett et al., 1983 and this paper). The reason for this discrepancy may lie in the choice of cells measured. Paroda and Rees (1971) measured interphase nuclei and “... mean $2 C$ values were obtained from the 10 lowest readings among the 20 nuclei presumed to be $2 C$ ". In the present study only $4 C$ late prophase cells were used but large interphase nuclei containing up to $10 \mathrm{pg}$ of DNA were found. Perhaps the previous estimates were unduly high because of the inclusion of polyploid cells.

A comparison of the DNA contents in tables 1 and 5 shows that the smallest estimate for maize (Seneca 60 ) is 2.8 fold larger than the largest estimate for $S$. bicolor (CMS), while the largest estimate for maize (Zapalote Chico Oaxaca 50) is 3.9 fold larger than the smallest estimate for $S$. bicolor (SII). This difference suggests that there may be difficulties in hybridising these genera since work on other crops indicates that stable hybrids are not usually produced in situations where parental genomes with equal chromosome numbers differ so greatly in size. Nonetheless if hybrids are produced the differences in genome sizes between the parents should be sufficient to enable the parental origin of each individual chromosome to be identified with certainty.

Acknowledgements This work was funded by a grant from the Overse:s Development Administration (grant number R3797). We would like to thank CIMMYT, J. F. Doebley, D. B. Walden, J. D. Smith and J. G. Scandalios for seed stocks, A. L. Rayburn and $H$. J. Price for access to their unpublished results, and J. B. Smith for measuring the DNA content of the maize inbred line W64A.

\section{REFERENCES}

ANDERSON, E. AND BROWN, W. L. 1952. Origin of corn belt maize and its genetic significance. In "Heterosis" ed. J. W. Gowen, pp. 124-148.

BARLOW, P. W. AND RATHFELDER, E. L. 1984. Correlations between the dimensions of different zones of grass root apices, and their implications for morphogenesis and differentiation in roots. Ann. Bot., 53, 249-260.
BENNETT, M. D. 1976. DNA amount, latitude and crop plant distribution. In "Current Chromosome Research" eds. K. Jones and P. E. Brandham. Elsevier/North Holland Biomedical Press, Amsterdam, The Netherlands, pp. 151-158.

BENNETT, M. D., SMITH, J. B. AND HESLOP-HARRISON, J. S. 1982. Nuclear DNA amounts in angiosperms. Proc. R. Soc. Lond., B 216, 179-199.

BENNETT, M. D. AND SMITH, J. B. 1976. Nuclear DNA amounts in angiosperms. Phil. Trans. Roy. Soc. Lond., B 274, 227274.

BENNETT, M. D., HESLOP-HARRISON, J. S., SMITH, J. B. AND WARD, J. P. 1983. DNA density in mitotic and meiotic metaphase chromosomes of plants and animals, J. Cell Sci., $63,173-179$.

DE WET, J. M. J. 1978. Systematics and evolution of Sorghum Sect. Sorghum (Gramineae). Amer. J. Bot., 65, 477-484.

DOEBLEY, J. F. AND ILTIS, H. H. 1980. Taxonomy of Zea (Gramineae). I. A subgeneric classification with key to taxa. Amer. J. Bot., 67, 982-993.

DOEBLEY, J. F. 1983. The maize and teosinte male inflorescence: A numerical taxonomic study. Ann. Missouri Bot. Gard., $70,32-70$.

DOEBLEY, J. F., GOOdMAN, M. M. AND STUBER, C. W. 1984. Isoenzymatic variation in Zea (Gramineae). Systematic Botany, 9, 203-218.

GU, M-H., MA, H-T. AND LIANG, G. H. 1984. Karyotype analysis of seven species in the genus Sorghum. J. Hered., 75, 196202.

HAKE, S. AND WALBoT, v. 1980. The genome of Zea mays, its organization and homology to related grasses. Chromosoma, 79, 251-270.

ILTIS, H. H. AND DOEBLEY, J. F. 1980. Taxonomy of Zea (Gramineae). II. Subspecific categories in the Zea mays complex and a general synopsis. Amer. J. Bot., 67, 9941004.

KATO, Y., T. A. 1976. Cytological studies of maize (Zea mays L.) and teosinte (Zea mexicana Schrader Kuntze) in relation to their origin and evolution. Univ. Mass. Agric. Expt. Sta. Bull. 635.

MASTENBRoEK, I., COHEN, C. E. AND DE WET, J. M. J. 1981. Seed protein and seedling isozyme patterns of Zea mays and its closest relatives. Biochem. Syst. Ecol., 9, 179-183.

MASTENBROEK, I. AND DE WET, J. M. J. 1983. Chromosome C-banding of Zea mays and its closest relatives. Can. J. Genet. Cytol., 25, 203-209.

MCCLINTOCK, B., KATO Y., T. A. AND BLUMENSCHEIN, A. 1981. Chromosome constitution of races of maize. Colegio de Postgraduados, Chapingo, Mexico.

PARODA, R. S. AND REES, H. 1971. Nuclear DNA variation in Eu-Sorghums. Chromosoma, 32, 353-363.

RAYBURN, A. L., PRICE, H. J., SMITH, J. D. AND GOLD, J. R. 1985. C-band heterochromatin and DNA content in Zea mays (L.). Amer. J. Bot., In press.

SMITH, J. S. C., GOODMAN, M. M. AND LESTER, R. N. 1981. Variation within teosinte. I. Numerical analysis of morphological data. Econ. Bot., 35, 187-203.

SMITH, J. S. C., GOODMAN, M. M. AND KATO Y., T.A. 1982. Variation within teosinte. II. Numerical analysis of chromosome knob data. Econ. Bot., 36, 100-112.

SMITH, J. S. C., GOODMAN, M. M. AND STUBER, C. W. 1984. Variation within teosinte. III. Numerical analysis of allozyme data. Econ. Bot., 38, 97-113.

TIMOTHY, D. H., LEVINGS III, C. S., PRING, D. R., CONDE, M. F. AND KERMICLE, J. L. 1979. Organelle DNA variation and systematic relationships in the genus Zea: Teosinte. Proc. Natl. Acad. Sci. (USA), 76, 4220-4224. 